\title{
Pengembangan Four-Tier Diagnostic Test Berbasis Website untuk Mengidentifikasi Miskonsepsi pada Materi Suhu dan Kalor
}

\author{
Lolika Saputri ${ }^{1}$, Maison ${ }^{2}$, Wawan Kurniawan ${ }^{3}$ \\ ${ }_{1,2,3}^{1}$ Universitas Jambi \\ 1email:lolikasaputri1@gmail.com
}

\begin{abstract}
ABSTRAK. Tujuan penelitian ini adalah mengembangkan four-tier diagnostic test berbasis web untuk mengidentifikasi miskonsepsi siswa SMP pada materi suhu dan kalor. Penelitian ini merupakan penelitian pengembangan (Research dan Development) dengan menggunakan model pengembangan ADDIE (Analysis, Design, Development, Implementation, Evaluation). Namun dalam penelitian hanya dibatasi sampai tahap Development karena tujuan penelitian sudah tercapai. Instrumen pengumpulan data berupa angket validasi ahli media. Data penelitian meliputi data kuantitatif berupa evaluasi validator serta data kualitatif berupa komentar dan saran yang diberikan oleh validator. Hasil penelitian menunjukkan bahwa produk layak digunakan berdasarkan validasi ahli dengan kategori sangat layak. Produk yang dihasilkan memiliki dua bagian utama, yaitu four-tier diagnostic test dan data hasil analisis four-tier diagnostic test.
\end{abstract}

Kata Kunci: Four-Tier; Miskonsepsi; Web

ABSTRACT. The aim of this study was to develop a web-based four-tier diagnostic test to identify junior high school stduent's misconceptions in temperature and heat. This research is a type of development research (Research and Development) using the ADDIE development model (Analysis, Design, Development, Implementation, Evaluation). However, in research it is only limited to the Development stage because the research objectives have been achieved. The data collection instrument was in the form of a media expert validation questionnaire. The research data includes quantitative data in the form of validator evaluation and qualitative data in the form of comments and suggestions given by the validator. The results showed that the product was suitable for use based on expert validation with the very feasible category. The resulting product has two main parts, namely the four-tier diagnostic test and data from the analysis of the four-tier diagnostic test.

Keywords: Four-Tier; Misconception; Web

\section{PENDAHULUAN}

Pembelajaran fisika merupakan sarana untuk mempelajari konsep, teori, prinsip dan hukum fisika yang dapat menjelaskan berbagai fenomena alam dan mengarah ke konsepsi yang dibangun di benak siswa. Dalam proses pembelajaran, masing-masing siswa bisa saja memiliki konstruksi pengetahuan yang berbeda terhadap sesuatu yang dilihatnya. Karena setiap siswa memiliki pemahaman dan pengalaman yang berbeda satu sama lain. Hal ini dapat menyebabkan ketidaksesuaian antara konsepsi siswa dengan konsep ilimiah (Wardana \& Maison, 2019:2).

Pada beberapa literatur ketidaksesuaian konsepsi siswa dengan konsep ilmiah disebut miskonsepsi. Miskonsepsi dapat berbentuk kesalahan hubungan yang tidak benar antar konsep, gagasan intuitif atau pandangan yang salah (Zafitri, Yahya \& Fitriyanti, 2019:35). Karena konsep-konsep pada fisika saling terkait satu sama lain, maka miskonsepsi yang terjadi tidak hanya berdampak pada konsep yang dipelajari, tetapi juga akan mempengaruhi konsep yang akan dipelajari setelahnya (Kamilah \& Suwarna, 2016: 214). Sejalan dengan hal itu Fitria (2014:48) mengatakan bahwa miskonsepsi bisa menjadi penghambat terhadap penerimaan pengetahuan-pengetahuan baru yang akan mempengaruhi proses belajar lebih lanjut yang pada akhirnya dapat menyebabkan rendahnya penguasaan konsep dan hasil belajar siswa. Oleh karena itu, miskonsepsi harus diatasi secepat dan sedini mungkin.

Sebelum mengatasi miskonsepsi persoalan mendasar yang menjadi masalah adalah bagaimana mengidentifikasi miskonsepsi itu sendiri. Miskonsepsi tidak dapat diketahui secara langsung, melainkan harus melalui tes agar guru benar-benar bisa membedakan antara siswa yang mengalami miskonsepsi dengan siswa yang tidak paham mengenai konsep yang diajarkan. Salah satu cara yang bisa digunakan untuk mendeteksi miskonsepsi yang dialami siswa ialah tes diagnostik.

Tes diagnostik adalah tes yang dapat memberikan gambaran akurat mengenai miskonsepsi yang dialami siswa berdasarkan informasi kesalahan yang dibuatnya (Fariyani, Rusilowati \& Sugianto, 2015:42). Ada 
beberapa jenis tes diagnostik yang digunakan untuk mendeteksi miskonsepsi diantaranya wawancara diagnostik, tes diagnostik tertulis (esai), tes pilihan ganda biasa, two-tier test, three-tier test dan four-tier test yang masing-masing memiliki kelebihan dan kekurangan dalam penggunaannya. Four-tier test merupakan pengembangan dari three-tier test, yaitu dengan menambahkan tingkat keyakinan untuk jawaban dan alasan. Four-tier test memiliki keunggulan dibandingkan dengan tes bentuk lain yaitu dapat membedakan tingkat keyakinan jawaban dan tingkat keyakiyan alasan sehingga dapat mendiagnosis lebih dalam miskonsepsi yang dialami oleh siswa (Gurel, Eryılmaz \& McDermott, 2015:998).

Four-tier test yang banyak dikembangkan umumnya masih berbentuk paper based test atau berbasis kertas. Pengidentifikasian miskonsepsi dengan menggunakan four-tier test berbasis kertas membutuhkan ketelitian dan memakan waktu cukup lama dalam pengoreksiannya (analisis data). Karena mengkombinasikan empat jawaban dari setiap tingkat untuk menganalisis miskonsepsi yang tejadi. Selain itu four-tier test berbasis kertas tidak dapat memberikan umpan balik yang cukup tentang kesalahan masing-masing siswa (Purnanto, et. al., 2018:291). Untuk mempermudah guru dalam mengidentifikasi miskonsepsi dan mengetahui secara spesifik presentase miskonsepsi siswa sehingga guru dapat memberikan bantuan sedini mungkin untuk mengatasi masalah miskonsepsi tersebut, maka peneliti mencoba mengembangkan four-tier test berbasis web.

Web dapat diartikan sebagai kumpulan halaman yang berisi informasi data digital baik berupa teks, gambar animasi, suara dan video atau gabungan dari semuanya yang disediakan melalui jalur koneksi internet (Abdullah, 2018:1). Penerapan instrument berbasis web ini tentunya memberikan banyak keuntungan diantaranya dapat mengurangi jeda waktu dalam melaporkan skor, meningkatkan efisiensi penilaian, mencapai fleksibilitas dalam hal waktu dan tempat serta dapat memberikan umpan balik langsung (Öz \& Özturan, 2018:67).

Suhu dan Kalor merupakan materi yang tidak begitu sulit dibandingkan dengan materi fisika lainnya, namun ternyata masih banyak siswa yang mengalami miskonsepsi pada materi tersebut. Seperti penelitian Maison, Safitri dan Wardana (2019:197) yang menemukan bahwa rata-rata miskonsepsi adalah sebesar 24,25\%. Selain itu penelitian Ni'mah, Kusairi dan Supriana (2019:586) dengan menggunakan instrumen tes two-tier menunjukkan bahwa siswa mengalami miskonsepsi pada materi suhu dan kalor sebesar 63\%. Contoh miskonsepsi yang sering terjadi adalah suhu dan kalor adalah hal yang sama. Berlatarbelakang hal tersebut peneliti bertujuan untuk menghasilkan four-tier diagnostic test berbasis web untuk mengidentifikasi miskonsepsi pada materi suhu dan kalor.

\section{METODE}

Jenis penelitian ini adalah penelitian dan pengembangan (Research dan Development). Penelitian pengembangan ini menggunakan metode Analysis, Design, Development, Implementation, and Evaluation yang dikenal dengan ADDIE. Menurut Branch (2009:2), ADDIE adalah sebuah proses yang berfungsi sebagai kerangka kerja panduan untuk mengembangkan produk pendidikan dan sumber belajar lainnya. Sesuai dengan namanya, model ADDIE terdiri dari lima langkah pengembangan yaitu Analysis (Analisis), Design (Desain), Development (Pengembangan), Implementation (Implementasi) dan Evaluation (Evaluasi). Namun pada penelitian ini dibatasi hanya sebatas tahap Development saja.

\section{Analysis}

Pada tahap analysis peneliti menganalisis permasalahan dasar dan potensi yang ada di lapangan terhadap pengembangan instrumen miskonsepsi berbasis web yang akan dikembangkan. Pada tahap ini peneliti melakukan studi literatur dan wawancara dengan guru IPA.

\section{Design}

Pada tahap ini peneliti membuat prototype yaitu produk awal yang dirancang dari produk yang akan dihasilkan dan megikuti four-tier diagnostic test materi suhu dan kalor yang telah ada yaitu yang dikembangkan oleh Maison, Safitri dan Wardana (2019) yang terdiri dari 9 item pertanyaan dan selanjutnya akan di program berbasis web.

\section{Development}

Pada tahap Development, produk awal yang telah dirancang akan di validasi oleh validator ahli media dengan menggunakan lembar validasi ahli media.

Mengidentifikasi miskonsepsi dengan four-tier diagnostic test ini dapat disusun berdasarkan kombinasi jawaban dan keyakinan dalam menjawab jawaban tersebut. Adapun kategori dari kombinasi jawaban four-tier diagnostic test dapat dilihat pada Tabel 1 . 
Tabel 1. Interpretasi Hasil Four-Tier Diagnostic Test

\begin{tabular}{|c|c|c|c|c|}
\hline \multicolumn{4}{|c|}{ Tahap } & \multirow{2}{*}{ Keputusan } \\
\hline $\mathrm{I}$ & II & III & IV & \\
\hline Benar & Yakin & Benar & Yakin & $\mathrm{SC}$ \\
\hline Benar & Yakin & Benar & Tidak Yakin & LK \\
\hline Benar & Tidak Yakin & Benar & Yakin & LK \\
\hline Benar & Tidak Yakin & Benar & Tidak Yakin & LK \\
\hline Benar & Yakin & Salah & Yakin & $\mathrm{FP}$ \\
\hline Benar & Yakin & Salah & Tidak Yakin & LK \\
\hline Benar & Tidak Yakin & Salah & Yakin & LK \\
\hline Benar & Tidak Yakin & Salah & Tidak Yakin & LK \\
\hline Salah & Yakin & Benar & Yakin & $\mathrm{FN}$ \\
\hline Salah & Yakin & Benar & Tidak Yakin & LK \\
\hline Salah & Tidak Yakin & Benar & Yakin & LK \\
\hline Salah & Tidak Yakin & Benar & Tidak Yakin & LK \\
\hline Salah & Yakin & Salah & Yakin & MSC \\
\hline Salah & Yakin & Salah & Tidak Yakin & LK \\
\hline Salah & Tidak Yakin & Salah & Yakin & LK \\
\hline Salah & Tidak Yakin & Salah & Tidak Yakin & LK \\
\hline
\end{tabular}

Sumber: Gurel, Eryılmaz \& McDermott (2015:999)

Jenis data dalam penelitian ini yaitu data kuantitatif dan data kualitatif. Data kuantitatif diperoleh dari lembar validasi ahli media sedangkan data kualitatif diperoleh dari komentar atau saran validator ahli media. Instrumen pengumpul data yang digunakan yaitu lembar validasi ahli media.

Adapun teknik analisis data yaitu: (1) data kualitatif, dilakukan dengan cara pengumpulan data, reduksi data, penyajian data serta penarikan kesimpulan dan verifikasi; (2) data kuantitatif, dilakukan dengan menganalisis butir-butir pernyataan lembar validasi ahli media. Data hasil validasi selanjutnya dikuantitatifkan dengan memberikan skor sesuai dengan bobot yang telah ditentukan pada skala likert. Skor skala likert yang digunakan adalah skala 4. Setelah data dikuantitatifkan selanjutnya dianalisis dengan menggunakan statistik deskriptif. Pertama dihitung persentase terlebih dahulu. Perhitungan persentase menurut Asyhari dan Silvia (2016:7) didapatkan dari:

$$
P=\frac{f}{n} \times 100 \%
$$

Keterangan:

$\mathrm{P}=$ persentase kelayakan

$\mathrm{F}=$ jumlah skor aspek penilaian yang akan dicari

$\mathrm{n}=$ jumlah skor maksimal aspek penilaian

Setelah didapatkan presentase, selanjutnya disesuaikan dengan kriteria penilaian skor rata-rata dari persentase angket validasi ahli dan angket respon tertera pada Tabel 2:

Tabel 2. Kriteria Penilaian Lembar Validasi Ahli Media

\begin{tabular}{ll}
\hline \multicolumn{1}{c}{ Rentang Presentase } & \multicolumn{1}{c}{ Kriteria } \\
\hline $81,25 \%<$ skor $\leq 100 \%$ & Sangat Layak \\
$62,50 \%<$ skor $\leq 81,25 \%$ & Layak \\
$43,75 \%<$ skor $\leq 62,50 \%$ & Cukup Layak \\
$25,00 \%<$ skor $\leq 43,75 \%$ & Tidak Layak \\
\hline \hline
\end{tabular}

Sumber: Sudijono (2009:37)

\section{HASIL DAN PEMBAHASAN}

Hasil dari penelitian pengembangan ini adalah berupa four-tier diagnostic test berbasis web untuk mengidentifikasi miskonsepsi pada materi suhu dan kalor serta penilaian mengenai kelayakan yang dilakukan oleh ahli media dengan menggunakan lembar validasi ahli media. Hasil dari setiap tahapan pada penelitian pengembangan ini dapat dilihat sebagai berikut:

1. Analysis

Berdasarkan hasil wawancara dengan salah satu guru IPA, guru menyatakan bahwa siswa mengalami kesulitan dalam memahami konsep-konsep fisika, salah satunya pada materi suhu dan kalor. Sehingga mengakibatkan hasil belajar sebagian siswa tidak mencapai KKM yang ditentukan. Guru mengatakan bahwa sejauh ini belum pernah diberikan tes untuk mengidentifikasi miskonsepsi siswa, karena belum tersedianya tes 
di sekolah dan guru belum pernah mengembangkan tes tersebut. Sehingga guru tidak mengetahui miskonsepsi apa saja yang terjadi pada siswa. Guru hanya memberikan tes pada aspek kognitif, berupa tes formatif berbasis kertas untuk mengukur hasil belajar siswa. Guru juga mengatakan bahwa di sekolah terdapat laboratorium komputer yang sudah terkoneksi jaringan internet, namun jarang dipakai.

Dari hasil studi literatur diketahui bahwa telah banyak dikembangkan instrumen identifikasi berupa four-tier diagnostic test berbasis kertas. Sedangkan yang berbasis digital atau website masih sedikit. Padahal instrumen berbasis kertas kurang praktis dalam penggunaan karena dinilai kurang ekonomis dan membutuhkan waktu cukup lama untuk pengoreksian (pengolahan data). Sementara instrumen berbasis website memiliki keunggulan-keunggulan yang dapat mengatasi berbagai kendala dalam penggunaan instrumen berbasis kertas.

Hasil dari tahap analisis ini menunjukkan bahwa diperlukannya instrumen untuk mengidentifikasi terjadinya miskonsepsi siswa pada pokok bahasan suhu dan kalor berbasis website.

2. Design

Pada pengembangan produk ini, ada beberapa tahap yang harus dilakukan peneliti setelah melakukan analisis. Pertama, peneliti mencari tahu dan menentukan jenis media yang sesuai dengan kebutuhan serta lingkungan pengguna. Kedua, melakukan instalasi aplikasi beberapa program yang dibutuhkan untuk mengembangkan media seperti XAMPP dan Dreamweaver. Selanjutnya, melakukan desain produk, diawali dengan pembuatan halaman awal dan dilanjutkan dengan halaman-halaman lain. Setelah mendesain halaman web, selanjutnya adalah pembuatan coding setiap halaman. Setelah itu di hosting pada domain lms-merdeka. Hosting dilakukan dengan cara upload coding yang telah selesai. Kemudian membuat database untuk menghubungkan bahasa pemrograman PHP dengan mengumpulkan data-data yang telah di coding. Setelah selesai instrumen identifikasi miskonsepsi pada pokok bahasan suhu dan kalor dapat di lihat pada link website.

Berikut ini adalah hasil pengembangan four-tier diagnostic test berbasis web untuk mengidentifikasi miskonsepsi pada materi suhu dan kalor.

a. Beranda

Halaman beranda akan tampil ketika pengguna mengklik link web

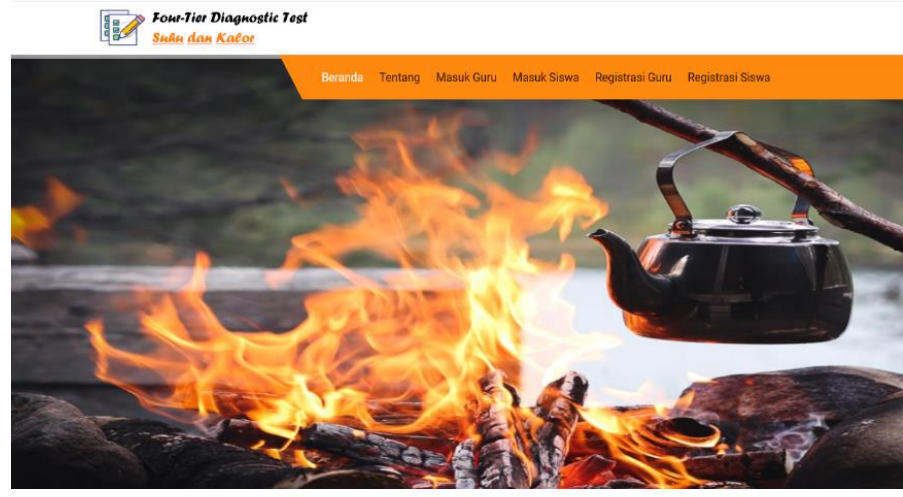

Gambar 1. Halaman Beranda

b. Login/Masuk

Login dengan memasukkan username dan password yang sebelumnya sudah terdafar
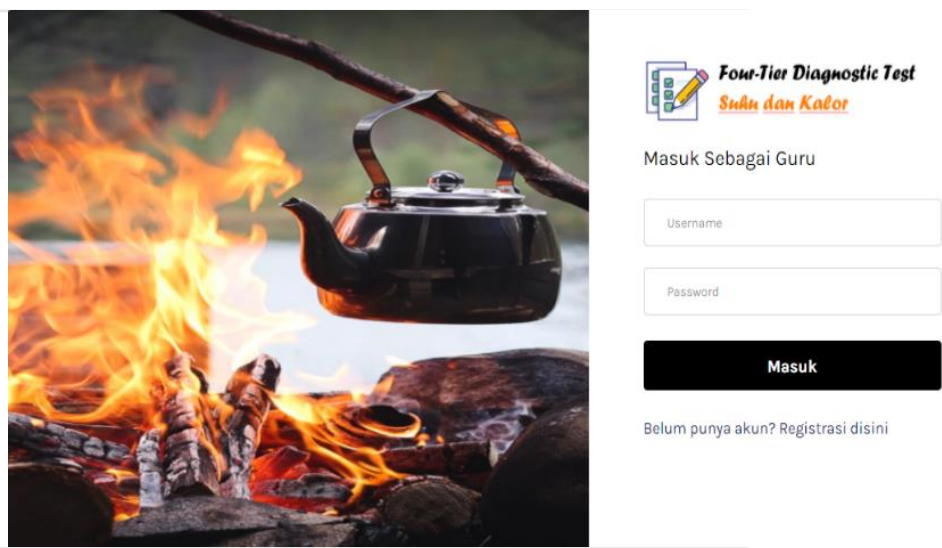

Belum punya akun? Registrasi disini

Gambar 2. Halaman Login 
c. Menu

Halaman menu akan tampil setelah pengguna berhasil login

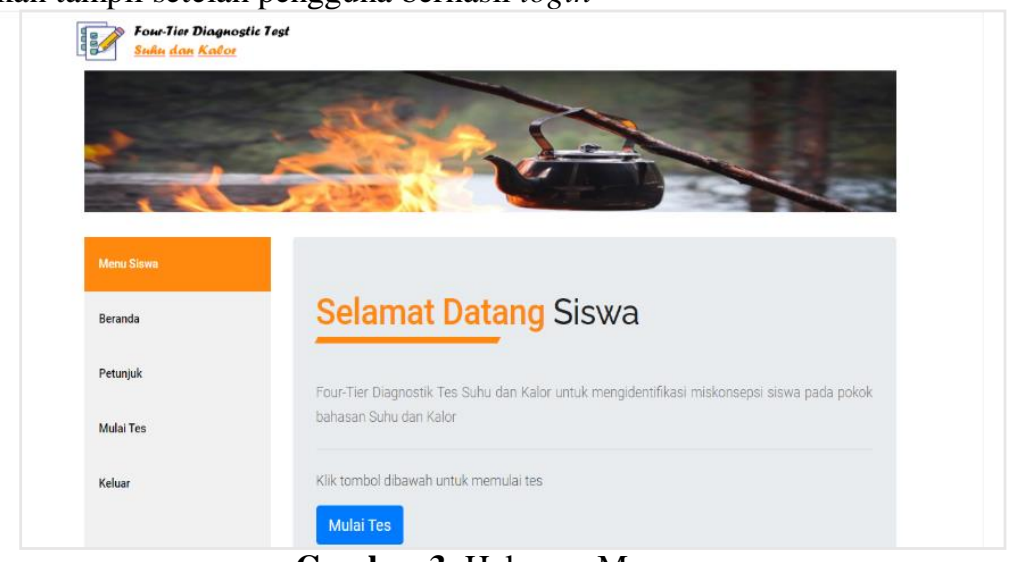

Gambar 3. Halaman Menu

d. Tes

Halaman tes akan tampil ketika pengguna mengklik tombol mulai tes

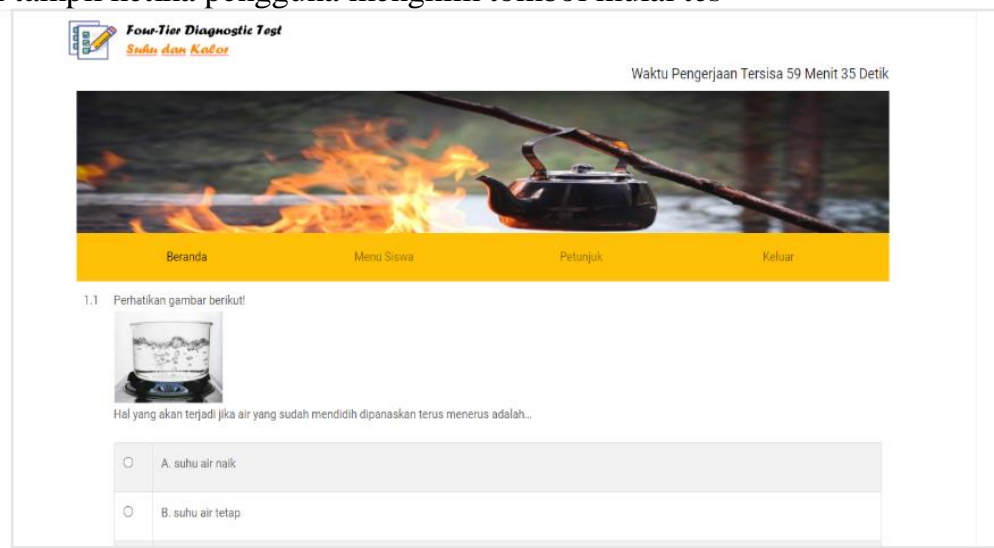

e. Hasil

Gambar 4. Halaman Tes

Halaman hasil akan tampil ketika pengguna mengirimkan jawaban tes

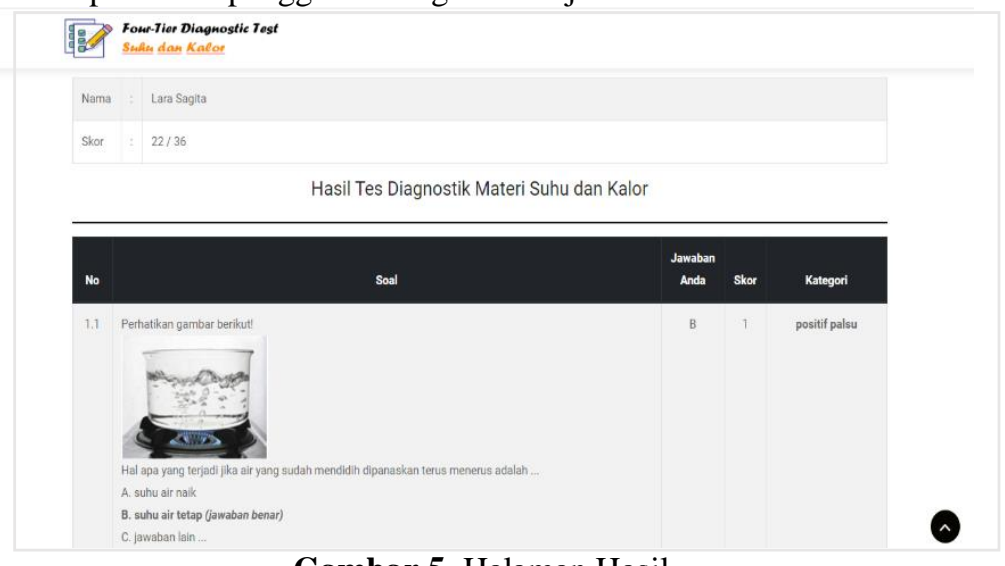

f. Data

Gambar 5. Halaman Hasil

Halaman data hanya dapat dilihat oleh guru, akan tampil ketika guru berhasil login dan mengklik tombol "Lihat Data". Halaman ini berisi tabel serta grafik miskonsepsi dan kategori pemahaman siswa. 


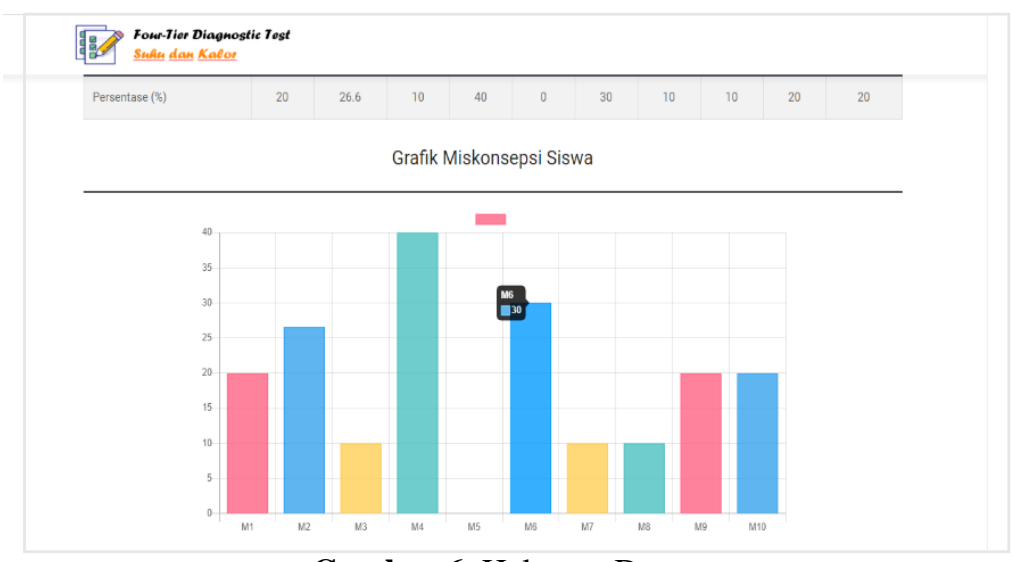

Gambar 6. Halaman Data

Produk yang dikembangkan bertujuan mempermudah guru dalam mengidentifikasi miskonsepsi pada materi suhu dan kalor yang terjadi pada siswa. Spesifikasi produk yang akan dibuat yaitu dalam bentuk web yang dapat diakses dimanapun dan kapanpun. Sehingga, pengguna web ini tidak terbatas, dengan kata lain dapat menjangkau akses yang cukup luas. Produk yang dikembangkan dapat menampilkan data miskonsepsi siswa secara langsung setelah siswa mengisi tes atau memberikan umpan balik kepada siswa. Produk juga dapat langsung secara otomatis menunjukkan kategori pemahaman dan miskonsepsi untuk masing-masing siswa per item soal serta menghasilkan persentase dan jumlah untuk masing-masing miskonsepsi pada materi suhu dan kalor yang disajikan dalam tabel dan grafik batang pada menu guru. Selain itu juga terdapat menu "pencarian" yang memudahkan guru untuk mencari data miskonsepsi setiap siswa.

Hal tersebut sesuai dengan pendapat Kusairi, Hidayat dan Hidayat (2017) yang menyatakan bahwa tes diagnostik berbasis $w e b$ adalah alat berbasis $w e b$ yang memungkinkan perancangan item diagnostik yang dapat memberikan umpan balik kepada siswa dan melaporkan miskonsepsi. Tes diagnostik berbasis web memiliki beberapa karakteristik sebagai berikut: (1) Dapat melayani tujuan formatif, yang dimaksudkan untuk membantu pembelajaran siswa; (2) Dapat memberikan umpan balik grafis kepada guru fisika tentang miskonsepsi siswa; (3) Umpan balik juga diberikan kepada siswa untuk membantu mereka mengatasi miskonsepsi; (4) Seorang siswa dapat mengakses tes diagnostik secara online; (4) Memiliki sistem database untuk menyimpan sejarah miskonsepsi siswa yang dapat dirujuk dalam proses pembelajaran; dan (5) Ini juga berlaku untuk subjek.

3. Development

Pada tahap ini dilakukan validasi ahli media dengan menggunakan lembar validasi ahli media. Aspek yang dinilai meliputi rekayasa perangkat lunak (meliputi maintainable, usability, kompabilitas dan reusable), komunikasi visual (meliputi: komunikatif, ilustrasi dan visual) dan aspek lainnya (petunjuk penggunaan). Validasi dilakukan dengan satu orang validator ahli media. Hasil validasi tahap I terlihat pada Tabel 3.

Tabel 3. Hasil Validasi Ahli Media Tahap I

\begin{tabular}{lcc}
\hline \multicolumn{1}{c}{ Aspek yang Dinilai } & Rata-rata skor penilaian & Kriteria \\
\hline Rekayasa perangkat lunak & $100,00 \%$ & Sangat Layak \\
Komunikasi Visual & $33,33 \%$ & Tidak Layak \\
Aspek Lain & $100,00 \%$ & Sangat Layak \\
Rata-rata keseluruhan & $77,77 \%$ & Layak \\
\hline
\end{tabular}

Kesimpulan: Produk yang dikembangkan layak untuk digunakan dengan melakukan perbaikan dan penyempurnaan lebih lanjut

Komentar dan saran dari validator antara lain:

1. Perbaiki judul tabel

2. Mengganti gambar yang kurang representatif

3. Mengganti Logo karena tidak representatif

4. Hilangkan kata Siswa pada kalimat "Selamat Datang Siswa" pada halaman menu siswa

5. Hilangkan kata Guru pada kalimat "Selamat Datang Guru" pada halaman menu guru 
Berdasarkan Tabel 3 diperoleh bahwa skor kelayakan produk adalah sebesar 77,77\% denga kriteria layak, namun masih terdapat komentar atau saran dari validator untuk perbaikan produk. Contoh perbaikan/ revisi produk yang dilakukan dapat dilihat pada Gambar 7.

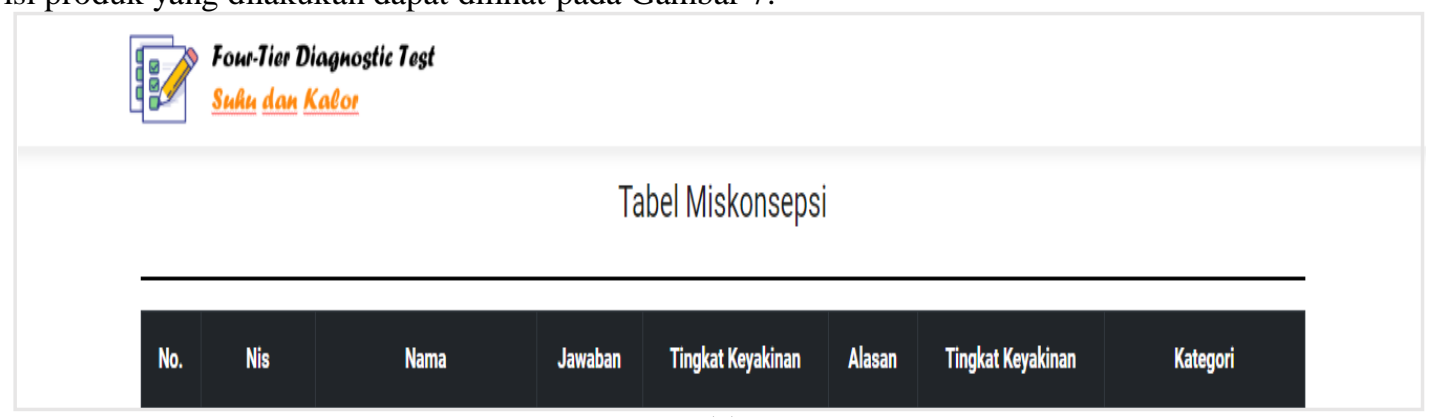

(a)

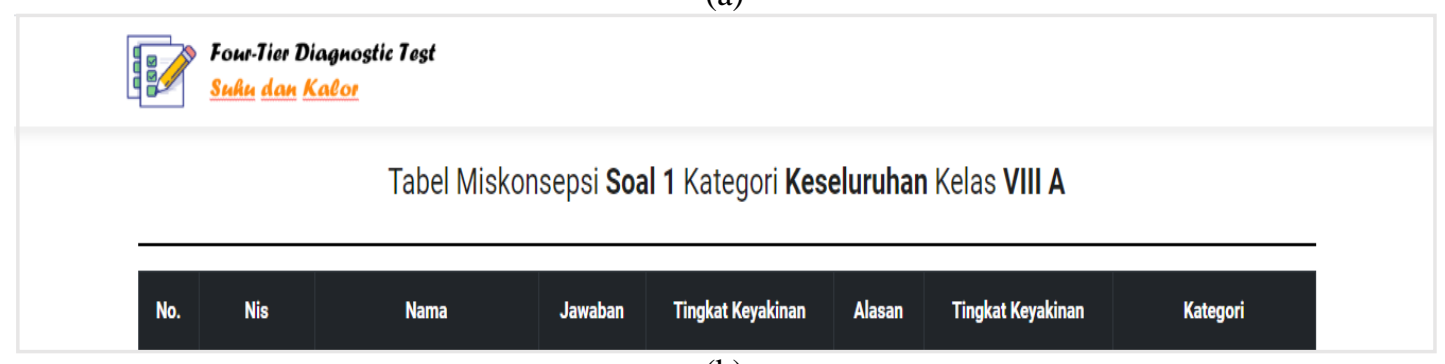

(b)

Gambar 7. (a) Judul tabel sebelum revisi, (b) setelah revisi

Selanjutnya setelah produk direvisi dilakukan validasi ahli media tahap II. Hasil validasi ahli media tahap II dapat dilihat pada Tabel 4.

Tabel 4. Hasil Validasi Ahli Media Tahap II

\begin{tabular}{lcc}
\hline \hline \multicolumn{1}{c}{ Aspek yang Dinilai } & Rata-rata skor penilaian & Kriteria \\
\hline Rekayasa perangkat lunak & $100 \%$ & Sangat Layak \\
Komunikasi Visual & $88,89 \%$ & Sangat Layak \\
Aspek Lain & $100 \%$ & Sangat Layak \\
Rata-rata keseluruhan & $93,52 \%$ & Sangat Layak \\
\hline Kesimpulan: Produk yang dikembangkan layak untuk digunakan &
\end{tabular}

Setelah dilakukan perbaikan/revisi produk sesuai dengan komentar dan saran validator, maka dilakukan validasi ahli media tahap II. Dari Tabel 4, diketahui bahwa skor kelayakan produk adalah sebesar 93,52\% dengan kriteria "Sangat Layak". Berdasarkan hasil analisis data validasi ahli media maka dinyatakan produk dapat digunakan untuk mengidentifikasi miskonsepsi siswa pada materi suhu dan kalor. Four-tier diagnostic test berbasis web ini diharapkan dapat memudahkan guru dalam melakukan identifikasi miskonsepsi yang dialami siswa. Sehingga guru dapat menentukan strategi pembelajaran yang tepat dan dapat membantu mengatasi miskonsepsi tersebut sebelum berlanjut ke tingkat tinggi yang akan mempengaruhi penerimaan konsep baru oleh siswa.

\section{SIMPULAN DAN SARAN}

Berdasarkan uraian pada hasil dan pembahasan maka dapat diambil kesimpulan bahwa telah dikembangkan four-tier diagnostic test berbasis web untuk mengidentifikasi miskonsepsi siswa SMP pada materi suhu dan kalor. Hasil pengembangan four-tier diagnostic test berbasis web dapat digunakan untuk mengidentifikasi miskonsepsi siswa SMP pada materi suhu dan kalor dengan skor kelayakan sebesar 93,52\% dengan kriteria "Sangat Layak".

Penelitian yang dilakukan masih terdapat kekurangan, sehingga saran yang dapat penulis berikan adalah pengembangan instrumen identifikasi miskonsepsi berikutnya lebih disempurnakan dengan menambahkan penjelasan atau pembahasan setiap soal sehingga dapat membantu mereduksi miskonsepsi siswa. 


\section{DAFTAR PUSTAKA}

Abdullah, R. (2018). 7 in 1 Pemrograman Web untuk Pemula: Cara Cepat dan Efektif Menjadi Web Programmer. Elex Media komputindo.

Asyhari, A., \& Silvia, H. (2016). Pengembangan Media Pembelajaran Berupa Buletin dalam Bentuk Buku Saku untuk Pembelajran IPA Terpadu. Jurnal Ilmiah Pendidikan Fisika Al-Biruni, 5(1), 1.

Branch, R. M. (2009). Instructional Design: The ADDIE Approach. Springer.

Fariyani, Q., Rusilowati, A., \& Sugianto. (2015). Pengembangan Four-Tier Diagnostik Test untuk Mengungkap Miskonsepsi Fisika Siswa SMA Kelas X. Journal of Innovative Science Education, 4(2), $41-49$.

Fitria, A. (2014). Miskonsepsi Mahasiswa dalam Menentukan Grup pada Struktur Aljabar Menggunakan Certainty of Response Index (CRI) di Jurusan Pendidikan Matematika IAIN Antasari. JPM IAIN Antasari, 01(2), 45-60.

Gurel, D. K., Eryllmaz, A., \& Mcdermott, L. C. (2015). A Review and Comparison of Diagnostic Instruments to Identify Students ' Misconceptions in Science. Eurasia Joural of Mathematics, Science \& Technology Education, 11(5), 989-1008.

Kamilah, D. S. \& Suwarna, I.P. 2016. Pengembangan Three-Tier Digital untuk Mengidentifikasi Miskonsepsi pada Konsep Fluida Statis. EDUSAINS, 8(2), 212-220.

Kusairi, S., et. al. 2017. Web-Based Diagnostic Test: Introducing Isomorphic Items to Assess Students' Misconceptions and Error Patterns. Chemistry: Bulgarian Journal of Science Education, 26(4), 2017. 526-539.

Maison, Safitri, I. C., \& Wardana, R. W. (2019). Identification of Misconception of High School Students on Temperature and Calor Topic Using Four-Tier Diagnostic Instrument. EDUSAINS, 11(2), 195-202.

Ni'mah, S. M., et. al. 2019. Profil Miskonsepsi Siswa SMA pada Materi Pembelajaran Suhu dan Kalor. Jurnal Pendidikan: Teori, Penelitian dan Pengembangan, 4(5), 586-592.

Öz, H., \& Özturan, T. (2018). Computer-Based and Paper-Based Testing : Does The Test Administration Mode Influence The Reliability and Validity of Achievement Tests?. Journal of Language and Linguistic Studies, 14(1), 67-85.

Purnanto, A. W., Suryawan, A., Andriani, A., \& Darwiastuti, B. R. (2018). Studi Eksplorasi dan Analisis Kebutuhan Terhadap Tes Berbasis Komputer. The 7th Research Colloqium 2018 STIKES PKU Mhammadiyah Surakarta, 291-297.

Sudijono, A. (2009). Pengantar Evaluasi Pendidikan. Jakarta: PT. Raja Grafindo Persada.

Wardana, R. W. \& Maison. 2019. Description students' conception and knowledge structure on electromagnetic concept. IOP Conf. Series: Journal of Physics: Conf. Series 1185012050.

Zaleha, Z., Samsudin, A., \& Nugraha, M. G. (2017). Pengembangan Instrumen Tes Diagnostik VCCI Bentuk Four-Tier Test pada Pengembangan Instrumen Tes Diagnostik VCCI Bentuk Four-Tier Test pada Konsep Getaran. Jurnal Pendidikan Fisika Dan Keilmuan, 3(1), 36-42. 